\title{
Ultrastructure of the adrenal gland of paca (Cuniculus paca, Linnaeus, 1766) in captivity
}

\section{Ultraestrutura da glândula adrenal de paca (Cuniculus paca, Linnaeus, 1766) em cativeiro}

\author{
Sérgio Pinter Garcia Filho ${ }^{* *}$ (i), Leandro Luis Martins² (i), Paulo Fernandes Marcusso ${ }^{3}$ (1),

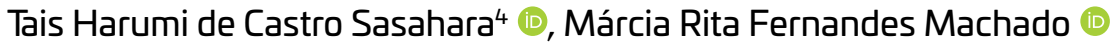

\begin{abstract}
Lowland paca (Cuniculus paca, Linnaeus, 1766) is a medium-sized rodent that belongs to the Brazilian fauna. Yet little information on its morphology is found in the specialized literature. Thus, the objective of the work was to study the morphology of the adrenal gland of paca by means of microscopic ultrastructure analysis. The adrenal gland secretes specialized substances in the body which promote biological functions of great importance and will provide valuable information to studies in comparative anatomy. Two (2) adult lowland pacas were used, male and female. Soon after death, the animals were positioned in the supine position; their abdominal cavities were opened by pre-retro umbilical and lateral incision followed by folding of the abdominal walls to expose the glands. The adrenal glands were removed; fragments were collected, fixed and prepared for ultrastructure observations using scanning electron microscopy and transmission electron microscopy techniques. It was observed that the adrenal glands of the paca have divisions as well as the limits of the cortical and medullary region, as well as the subdivisions of the glomerulosa, fasciculated and reticulated areas of the cortical region as in other rodents. An ultrastructure of cells and their components also showed a lot of similarity to that already demonstrated in different rodents.
\end{abstract}

KEYWORDS: Electron microscopy; Rodent; Suprarenal; Wild animals.

RESUMO: A paca (Cuniculus paca, Linnaeus, 1766) é um roedor de médio porte pertencente à fauna brasileira. Ainda assim, pouca informação sobre sua morfologia é encontrada na literatura especializada. Assim, o objetivo do trabalho foi estudar a morfologia da glândula adrenal da paca por meio da análise microscópica ultraestrutural. A glândula adrenal secreta no corpo substâncias especializadas que promovem funções biológicas de grande importância e fornecerão informações valiosas aos estudos de anatomia comparada. Foram utilizadas duas (2) pacas adultas, um macho e uma fêmea. Logo após a morte, os animais foram posicionados em decúbito dorsal; suas cavidades abdominais foram abertas por incisão pré-retro umbilical, seguida de rebatimento das paredes abdominais para expor as glândulas. As glândulas suprarrenais foram removidas; fragmentos foram coletados, fixados e preparados para observaçóes ultraestruturais por meio de microscopia eletrônica de varredura e microscopia eletrônica de transmissão. Observou-se que as glândulas supra-renais da paca apresentam divisões bem como os limites da região cortical e medular, bem como as subdivisóes da glomerulosa, áreas fasciculadas e reticuladas da região cortical como em outros roedores. Uma ultraestrutura de células e seus componentes também mostrou muita similaridade com aquela já demonstrada em diferentes roedores.

PALAVRAS-CHAVE: Microscopia eletrônica; Roedor; Suprarrenal; Animais selvagens.

\section{INTRODUCTION}

The paca is the second largest rodent in the Brazilian fauna; presenting a robust and vigorous body in both male and female adults; the average length from the nose to the tip of the tail is $70 \mathrm{~cm}$ for males, and $60 \mathrm{~cm}$ for females. The body weight ranges from $5-10 \mathrm{~kg}$ and can reach up to $14 \mathrm{~kg}$
(PACHALY et al., 2001). In addition to high utilization of carcass, a meat with high protein value and good acceptance in the market due mainly to its flavor. Brazil is among the countries with farms authorized for commercial purposes (GOMES et al.,2013). Its importance, in addition to commercial considerations, is that it could well affect the scope of science; as a

\footnotetext{
'Departamento de Medicina Veterinária, Universidade Estadual de Maringá, Umuarama/PR, Brasil 2Departamento de Anatomia, Universidade Estadual de Londrina, Londrina/PR, Brasil

IInstituto de Ciências Agrárias e Veterinária, Universidade Federal dos Vales do Jequitinhonha e Mucuri, Unaí/MG, Brasil

${ }^{4}$ Faculdade de Medicina Veterinária e Zootecnia, Universidade de São Paulo, São Paulo/SP, Brasil

${ }^{5}$ Departamento de Morfologia Animal, Faculdade de Ciências Agrárias e Veterinárias, Universidade Estadual Paulista, Jaboticabal/SP, Brasil

*Corresponding author: sgarciafilho@hotmail.com

Received: 19/09/2019. Accepted: 25/05/2020
} 
good alternative for research purposes, for animal modeling, and towards preservation of the species (SANTOS, 2006).

As the adrenal glands play an important role in maintaining the homeostasis of the body, since they are responsible for the production of hormones that, in addition to the use for normal organic functioning, provide survival in stressful situations (DYCE; SACK; WENSING 2019).

Adrenal glands, in pairs, which are also called suprarenals, develop separately, and are located on either side of the median plane, above the cranial extreme of each kidney; they have no functional relationship between them. Embryologically is applied by two layers: a peripheral layer, originating from the mesoderm, called if the cortex has a yellowish color, while a central layer, a medullary, originates from the ectoderm and the grayish color (JUNQUEIRA; CARNEIRO 2017, (KONIG; LIEBICH 2016, GARCIA FILHO et al., 2014).

The ultrastructure of the porcupine (Hystrix cristata) adrenal gland presents a fasciculate zone with cells having irregular shaped nuclei, an endoplasmic reticulum, large mitochondria and lipid vacuoles. The reticular zone appears as irregular cords and is smaller than the other two areas of the cortex. Chromaffin cells stand out in the medullary region, spherical and solitary nuclei. Nucleoli are well defined, and not infrequently, up to three nucleoli per cell are observed. The epinephrine storage granules are similar to norepinephrine granules in terms of size and shape. The cytoplasms of chromaffin cells contain numerous mitochondria, lysosomes, and the endoplasmic reticulum with associated ribosomes. Cortical cells are observed in conjunction with chromaffin cells in the cortical-medullary limit, their cytoplasms are mainly occupied by large rounded or ovoid mitochondria (YILMAZ; GIRGIN 2005).

When analyzing the Rattus norvegicus adrenal gland ultrastructure one observes the presence of many cortex microvessels, especially in the fasciculate zone, presenting well defined valves and suggesting a micro-functional role associated with circulation of blood and hormones (WAN EZUMI et al., 2007). Cells of the glomerulus zone contain scarce lipid droplets associated with well-developed smooth endoplasmic reticuli and smaller rough endoplasmic reticuli. The cortical cells in the adrenal gland fasciculate zone present endoplasmic reticuli, round or ovoid mitochondria with tubular crests, and lipid vacuoles. In the reticular zone, the cells present prominent smooth endoplasmic reticuli, and electron-dense irregular lipofuscin aggregates, as well as lysosomes, and ovaloid mitochondria with tubular crests, similar to those observed in cells of the fasciculate zone. Cells in the medulla contain neuroendocrine granules that vary in size and appearance, ranging from $150-350 \mathrm{~nm}$ in diameter. The adrenaline-secreting cells have small spherical neuroendocrine granules, almost entirely occupied by electron-dense material. Noradrenaline secretory cells have larger neuroendocrine granules with an apparent electron lucent layer in the interior of the membrane (STEVENS; LOWE, 1991).
When considering the assumptions presented, the objective of this article was to describe the ultrastructure of the adrenal glands of this rodent through studies involving scanning and transmission electron microscopy.

\section{MATERIAL AND METHODS}

For macroscopic and histological descriptions, two adult pacas were used, one male $(10,2 \mathrm{~kg})$ and one female $(8,6 \mathrm{~kg})$. The animals were considered roster extras from the Wild Animal Sector of the Department of Animal Science of the Faculty of Agrarian and Veterinary Sciences at Jaboticabal - UNESP, therefore they were selected for study aiming to maintain the balance between males and females in the breeding. It is registered with the Instituto Brasileiro do Meio Ambiente e dos Recursos Naturais Renováveis- IBAMA as a breeder of specimens of Brazilian fauna for scientific purposes, under registration number: 482508 .

The euthanasia of the animals was performed by intramuscular administration of midazolam $(3 \mathrm{mg} / \mathrm{kg}$ of body weight), in addition to an association of ketamine $(80 \mathrm{mg} /$ $\mathrm{kg}$ of body weight) and xylazine hydrochloride $(4.0 \mathrm{mg} / \mathrm{kg})$, applied intramuscularly.

For the ultrastructure study, segments of two glands were collected, fixed and processed for ultrastructural analysis. For the evaluation by means of scanning electron microscopy, the material analyzed was prepared according to the methodology established by the electron microscopy laboratory at FCAV/UNESP. The samples were fixed in glutaraldehyde solution $2.5 \%$ for 24 hours, rinsed in $0.1 \mathrm{M}$ phosphate buffer $\mathrm{pH} 7.4$, post-fixed in osmium tetroxide $1 \%$ for two hours, rinsed again in phosphate buffer, dehydrated in an increasing series of alcohols (30 to 100\%), for at least 20 minutes each phase, dried to the critical point in the diagnostic EMS ${ }^{\circledast}$ 850 , metallized with atoms of gold in diagnostic DESK II ${ }^{\oplus}$ DESK II $^{\circledR}$ (DESK II DETON VACCUN NJ, USA), and examined by scanning electron microscope Jeol ${ }^{\oplus}$ (Jeol JSM $5410^{\circledR}$ - Tokyo - Japan), operating with an electron beam of $15 \mathrm{keV}$, and certain specimens were documented.

For the transmission electronic microscopy evaluations the samples were fixed in glutaraldehyde solution $2.5 \%$ for 24 hours, rinsed in $0.1 \mathrm{M}$ phosphate buffer $\mathrm{pH} 7.4$, postfixed in osmium tetroxide $1 \%$ for two hours, rinsed again in phosphate buffer, dehydrated in an increasing series of alcohols $(50,60,70,80,90,100 \%)$, and then infiltrated with a (1:1) ethanol:resin blend (Epon) for one hour. Afterwards, the fragments were imbedded in Epon resin. Semi-fine slices were stained with toluidine blue and used to locate glandular epithelium. Ultrathin sections were then contrasted with $4 \%$ uranyl acetate and $0.3 \%$ lead citrate, both at $\mathrm{pH} 12$, and then observed and photographed in a transmission electron microscope $\left(\mathrm{JEOL}^{\circledR}\right.$ model 1010), at the Faculdade de Medicina de Ribeirão Preto, of the University of São Paulo. 
This research was approved by the Ethics Committee on Animal Use (CEUA) FCAV, Campus at Jaboticabal, UNESP, protocol no. 019411-11, in accordance with the Ethical Principles in Animal Experimentation adopted by the Brazilian College of Animal Experimentation (COBEA).

\section{RESULTS}

The male had glands weighing $1.38 \mathrm{~g}$ on the right and $1.49 \mathrm{~g}$ on the left. While those of the female presented $1.66 \mathrm{~g}$ to the right and $1.91 \mathrm{~g}$ to the left.

The paca adrenal glands were smooth and elongated and paired, with one located on the cranial pole of each kidney. When analyzing the ultrastructure microscopy of the gland, its rounded shape and smooth surface are readily observed (Figure 1).

The gland was observed divided into two layers, the peripheral cortical layer and the central medullary layer (Figure 2). The glomerulous zone is located just below the connective tissue capsule, being composed of pyramidal or columnar cells,



Figure 1. Scanning electron micrograph of the adrenal gland in an adult paca, observing its rounded shape and smooth surface.

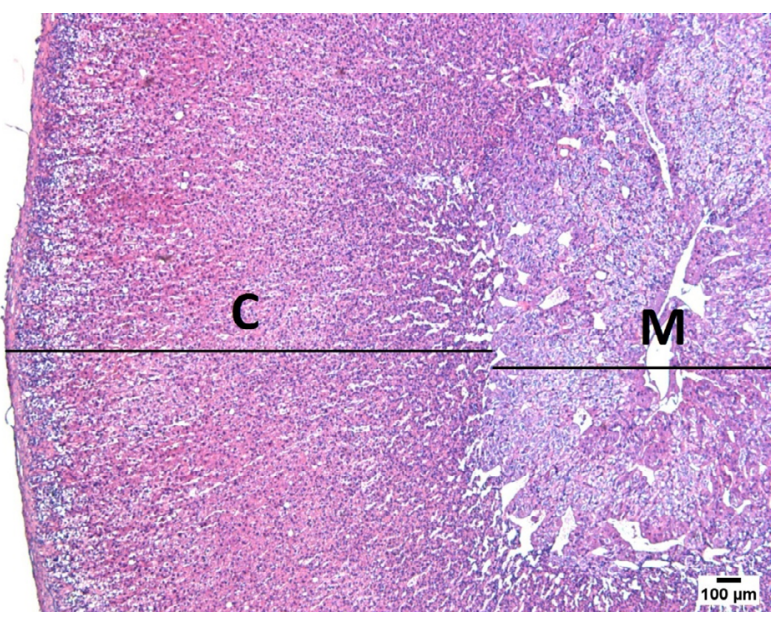

Figure 2. Photomicrograph of adrenal gland in an adult paca, verifying in (C) the cortical layer, and in (M) the medulla (Increase 50x, Hematoxylin and Eosin). organized in cords surrounded by blood capillaries. The fasciculated area of the paca's adrenal has an arrangement in strings of one or two cells thick, straight and regular, similar to bundles, interspersed by capillaries and arranged perpendicularly to the organ's surface. The reticulated area, on the other hand, contains cells arranged in irregular cords, its cells are smaller than those of the other two layers, and projections of this layer appear within the medullary region, which is composed of polyhedral cells organized in rounded cords or agglomerates, supported by a network of fibers and their reticular cells involved by a large number of blood vessels.

The division of the gland into two layers, cortical and medullary and its central vein are also noted with scanning electron microscopy (Figure 3).

The presence of microvessels in the cortex (especially in the fasciculate zone) and blood red cells were also observed (Figure 4).

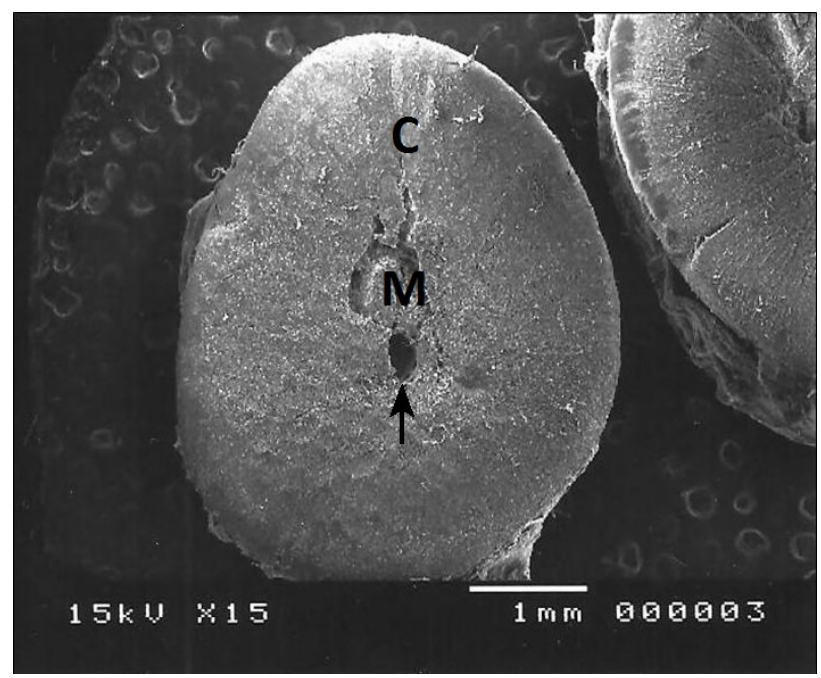

Figure 3. Scanning electron micrograph of the adrenal gland in an adult paca, where it was possible to observe as medullary (M) and cortical (C) layers and a central vein (arrow).

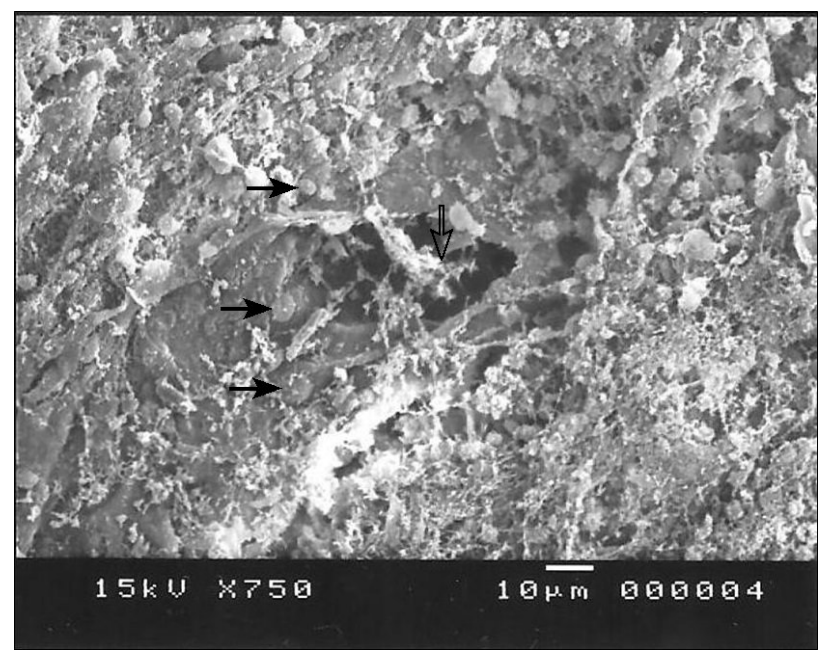

Figure 4. Scanning electron micrograph of the adrenal gland in an adult paca, where it was possible to observe the presence of cortex microvessels, in the fasciculate zone (open arrow) and red blood cells (arrows). 
With transmission electron microscopy the paca's adrenal gland ultrastructure presents fasciculate zone cells with rough endoplasmic reticulum in highlight, large rounded mitochondria and lipid vacuoles (Figure 5).

Reticular zone cells contain oval and elongated mitochondria, a large amount of elastic fibers, lipid vacuoles similar to those observed in fasciculate zone cells, and smooth endoplasmic reticulum in highlight (Figure 6 and 7).

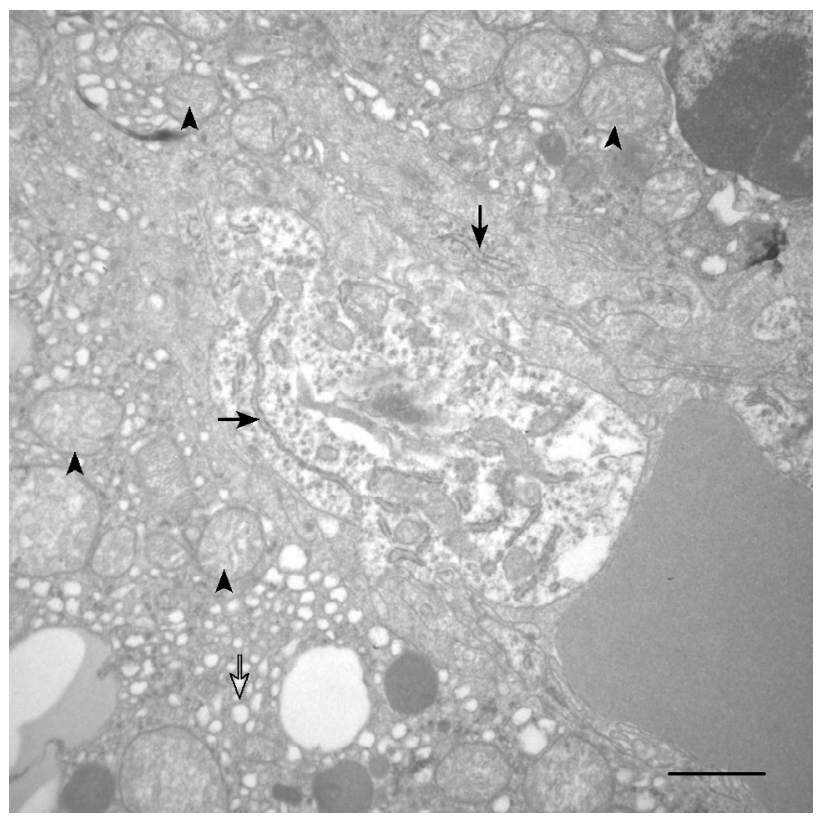

Figure 5. Transmission electron micrograph of adrenal gland in an adult paca, where it was possible to observe the fasciculate zone with cells presenting roughendoplasmic reticulum (arrows), rounded mitochondria (arrow head) and lipid vacuoles (open arrow) (Increase 14kx; Bar: $1 \mu \mathrm{m}$ ).

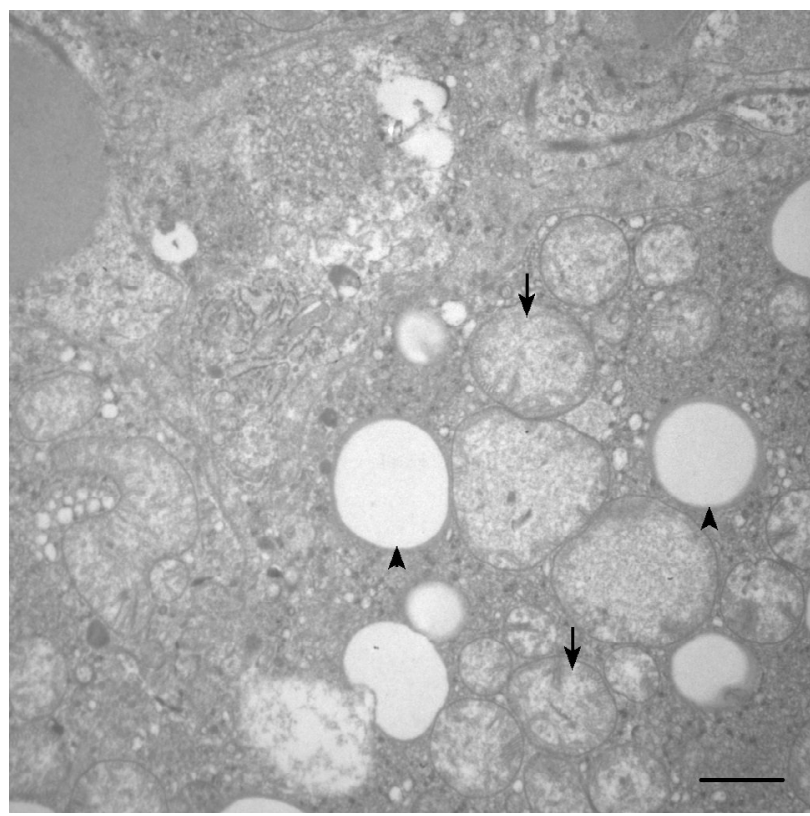

Figure 6. Transmission electron micrograph of adrenal gland in an adult paca, where it was possible to observe a reticulate area with cells presenting smooth endoplasmic reticulum (open arrow), rounded and elongated mitochondria (arrows), and lipid vacuoles (arrow head) (Increase 14kx; Bar: $1 \mu \mathrm{m}$ ).
The glomerulus zone cells contain scarce lipid droplets, and well developed smooth endoplasmic reticuli. The medullary region the cytoplasms of chromaffin cells contain numerous mitochondria; ribosome associated endoplasmic reticuli, and neuroendocrine granules that vary in size and appearance in which the adrenaline granules are smaller and more dense, whereas noradrenaline are larger and less dense (Figure 7 ).

In the paca, it is noted in the medullary region adrenaline secretory cells having small spherical neuroendocrine granules, almost entirely occupied by electron-dense material; and in addition to well-defined nuclei and nucleoli the noradrenaline secretory cells have larger neuroendocrine granules with an apparent electron lucent layer in the interior of the membrane (Figure 8).

\section{DISCUSSION}

Modern electron microscopy instruments such as those used in this study offer a detailed degree of structural, spectroscopic and compositional characterizations of the adrenals of the pacas that made it possible to affirm their similarities and differences with the adrenal glands already described from other mammals (JEANDUPEUX et al., 2002; WILLIAMS; CARTER, 2009)

Upon analysis of the paca adrenal gland, it was found to present two distinct layers as to origin and function: the external (cortex) and internal (medulla), as was reported by König; Liebich (2016) for domestic animals; by Junqueira; Carneiro (2017) for humans; and by Garcia Filho et al. (2014) using light microscopy for the paca.

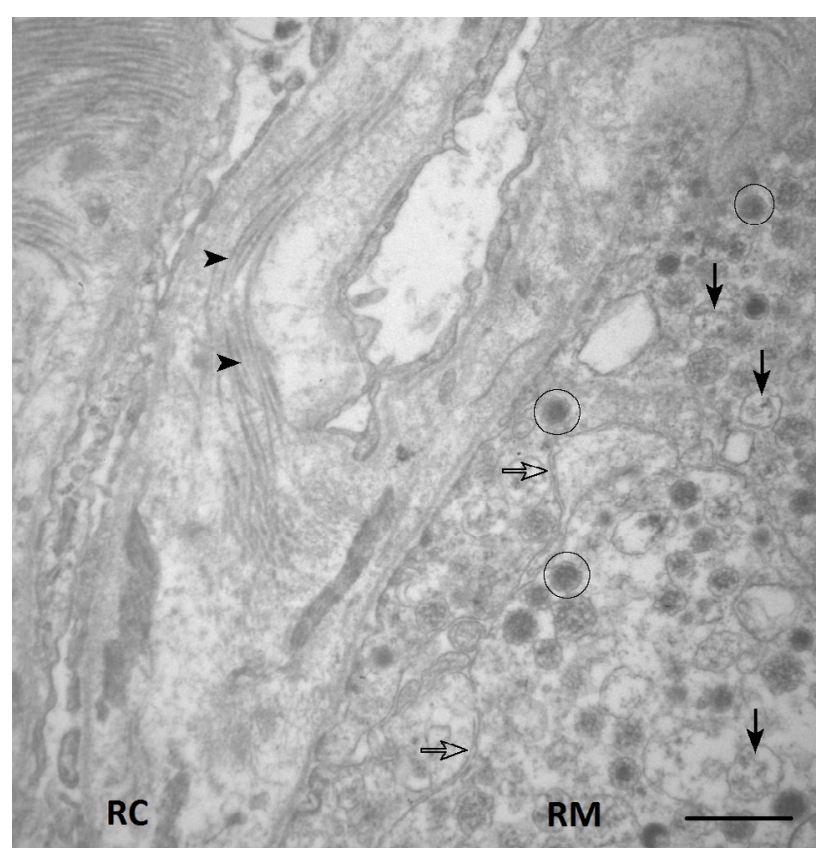

Figure 7. Transmission electron micrograph of adrenal gland in an adult paca, where it was possible to observe the cortical region (RC), and the medullary region (RM). In the cells of the medullary region note the endoplasmic reticulum (open arrow), rounded mitochondria (arrows), and neuroendocrine granules (circles). In the cortical region, observe the large number of elastic fibers in the reticulated area (arrow head) (Increase 20kx; Bar: $1 \mu \mathrm{m}$ ). 
It was possible to observe that the paca's adrenal cortex divides into three zones or layers: glomerulosa (external), fasciculata and reticular, as observed by Rosol et al. (2001), Bacha Jr; Bacha (2003), Yilmaz; Girgin (2005) and Junqueira; Carneiro (2017), which is contrary to Gude et al. (1982) who reported two distinct zones for rats, perhaps due to the low technology of the time that prevented the correct observation of the different zones.

In the cortical region, the presence of microvessels in the cortex and red blood cells was observed through scanning electron microscopy, especially in the fasciculated area, as seen by Wan Ezumi et al. (2007). Also in the fasciculated zone, cells with ultrastructure typical of glucocorticoid-secreting cells were observed, such as highlighted rough endoplasmic reticulum,

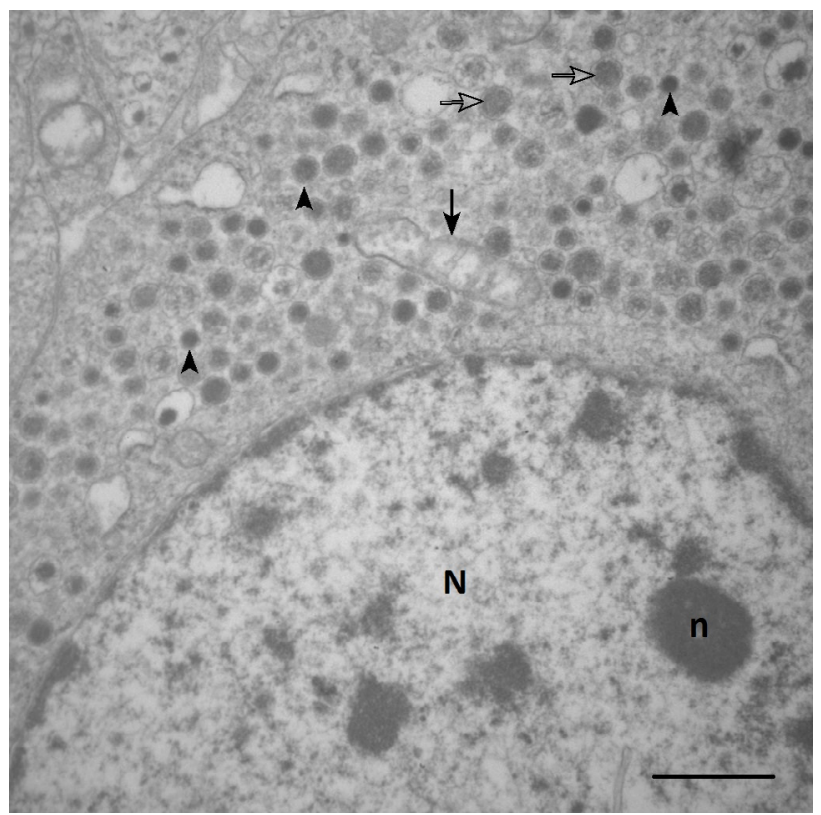

Figure 8. Electron micrograph of transmission of the adrenal gland in the adult range, where it was possible to view details of a cell in the medullary region presenting a well-defined cell nucleus ( $\mathrm{N}$ ) and nucleolus (n), mitochondria (arrow), neuroendocrine granules producing adrenaline (arrow head) and neuroendocrine granules producing noradrenaline (open arrow) (Increase 20kx; Bar: $1 \mu \mathrm{m}$ ). large round mitochondria and lipid vacuoles. Similar to the findings observed by Yilmaz; Girgin (2005) and Stevens; Lowe (1991).

The cells in the reticular zone contained elongated oval mitochondria, large amounts of elastic fibers, lipid vacuoles and highlighted smooth endoplasmic reticulum, as reported by Stevens; Lowe (1991). Similar morphology of androgenic hormone-secreting cells.

The cells of the glomeric zone, on the other hand, presented few lipid droplets and smooth endoplasmic reticules, well developed (STEVENS; LOWE 1991). Typical morphology of aldosterone-secreting cells in other mammals (JUNQUEIRA; CARNEIRO 2017).

In the medullary layer in the cytoplasm of cells, numerous mitochondria, endoplasmic reticulum associated with the ribosome and neuroendocrine granules were found that varied in size and appearance, as indicated by the descriptions of Yilmaz and Girgin (2005). The neuroendocrine granules of epinephrine secreting cells (adrenaline) were observed with a lower electron density and were differentiated from noradrenaline granules by a small empty space located between the granule and the limiting membrane, as reported in the literature (STEVENS; LOWE 1991). Such ultrastructural characteristics are typical of catecholamine-secreting cells.

Specifically in relation to the paca neuroendocrine granules, we can say that they are round and similar to those found in rodents such as rats (COUPLAND, 1965), hamsters (YATES, 1964), mice (JURECKA et al., 1978) and rabbits (COUPLAND; RUTHERFORD, 1968, 1970). And they have a different morphology than those found in porcupines that have rod morphology (YILMAZ; GIRGIN 2005).

\section{CONCLUSIONS}

Under the conditions in which this experiment was carried out, it can be inferred that the adrenal gland of pacas is ultrastructurally similar to the other rodents described in the literature. And which scanning and transmission microscopy techniques were satisfactory for the description of the main ultrastructural characteristics of this endocrine organ in this species.

\section{REFERENCES}

BACHA JR, W. J.; BACHA, L. M. Atlas colorido de Histologia Veterinária. 2. ed. São Paulo: Roca, 2003. 472p.

COUPLAND, R. E. Electron microscopic observations on the structure of the rat adrenal medulla. Journal of Anatomy, v. 99, p. 231-254, 1965.

COUPLAND, R. E.; WEAKLEY, B. S. Developing chromaffin tissue in the rabbit: an electron microscopic study. Journal of Anatomy, v. 102, p. 425-455, 1968.
COUPLAND, R. E.;WEAKLEY, B. S. Electron microscopic observations on the adrenal medulla and extra-adrenal chromaffin tissue of the postnatal rabbit. Journal of Anatomy, v. 106, p. 213-231, 1970.

DYCE, K. M; SACK, O. M.; WENSING, G. J. C. Tratado de Anatomia Veterinária. 5.ed. Rio de Janeiro, RJ: St. Louis: Elsevier, 2019. 872p.

EACHO, P. I.; COLBY, H. D. Regional distribution of microsomal drug and steroid metabolism in the guinea pig adrenal cortex. Life Sciences, v. 32, p. 1119-1127, 1983. 
GARCIA FILHO, S. P. et al. Morfologia da glândula adrenal da paca (Cuniculus paca, L. 1766). Biotemas, v. 27 n. 2, p. 163-170, 2014.

GOMES, C.; KARAM, L. B.; MACEDO, R. E. F.Atributos de qualidade da carne de paca (Agouti paca): perfil sensorial e força de cisalhamento. Arquivo Brasileiro de Medicina Veterinária e Zootecnia, v. 65, p. 559-565, 2013.

GUDE, W. D.; COSGROVE, G. E.; HIRSCH, G. P. Histological Atlas of the Laboratory Mouse. New York and London: Plenum press, 1982. 164p.

HENRIKSON, R. C.; KAYE, G. I.; MAZURKIEWICZ, J. E. Adrenal gland. In: The National Medical Series for Independent Study Histology: International edition Baltimore Williams \& Wilkins, 1997. p. 359-365

JEANDUPEUX, O. et al. Use of Scanning capacitance Microscopy for Controlling Wafer Processing. Microelectronics Reliability, v. 42, p. 225-231, 2002.

JUNQUEIRA, L. C. U.; CARNEIRO, J. Histologia básica, 13. ed. Rio de Janeiro: Guanabara Koogan, 2017. 568p.

JURECKA, W.; LASSMAN, H.; HÖRANDER, H. The proliferation of adrenal medullary cells in newborn and adult mice. A light and electron microscopic autoradiographic study. Cell and Tissue Research, v. 189, p. 305-312, 1978.

KARADAG, $H$. et al. Tavșanda ovariektominin adrenal bez üzerinde morfolojik etkileri. F.Ü. Sağlık Bilimleri Dergisi, v. 9, p. 165-173, 1995.
KÖNIG, H. E.; LIEBICH, H. G. Anatomia dos animais domésticos. 6. ed. São Paulo: Artmed, 2016. 824p.

PACHALY, J. R. et al. Order Rodentia (Rodents). In: FOWLER, M. E.; CUBAS, S. Z. Biology, medicine, and surgery of South America wild animals. lowa: lowa State University Press, 2001. p. 225-237.

ROSOL, T.J. et al. Adrenal Gland: Structure, Function, and Mechanisms of Toxicity. Toxicologic Pathology, v. 29, n. 1, p. 4l-48, 2001

SANTOS, B. F. Modelo Animal. In: ANDRADE, A.; PINTO, S. C.; OLIVEIRAR. S. Animais de laboratório: criação e experimentação. Rio de Janeiro: Fiocruz, v. 2, p. 23-24. 2006.

STEVENS, A.; LOWE, J. S. Histology. London: Gower Medical Publishing, p.260-263. 1991.

WAN EZUMI, M. F. et al. Morphological Characteristics of the Adrenals of Rattus Norvegicus: A Revisit By Scanning Electron Microscopy. Annals Of Microscopy, v. 7, p. 62-69, 2007.

WILLIAMS, D. B.; CARTER, C. B. Transmission Electron Microscopy. A Textbookfor Materials Science. 2. ed. NewYork: Springer, 2009. 837p.

YATES, R. D. A light and electron microscopic study correlating the chromaffin reaction and granule ultrastructure in the adrenal medulla of the Syrian hamster. The Anatomical Record, v. 149, p. 237-250, 1964.

YILMAZS.; GIRGIN, A. Light and electron microscopic observations on the structure of the porcupine (Hystrix cristata) adrenal gland. Veterinarski Arhiv, v. 75, n. 3, p. 265-272, 2005. 